\title{
70'İNCİ YILDÖNÜMÜ AÇILIŞ KONUŞMALARI
}

\section{I}

\author{
Cumhurbaşkant Süleyman DEMIREL'in Konuşmalan
}

Ankara Üniversitemizin değerli yöneticilerini, Sayın Rektörü, Sayın Dekanlan ve Ankara Üniversitemizin değerli öğretim ve eğitim kadrosunu, değerli ilim adamlanmizı, değerli misafirlerimizi sevgiyle selâmlıyor, Ankara Hukuk Fakültesinin değerli mensubu gençleri ve bu sene mezun olan Hukuk Fakültesinin değerli öğrencilerini, Adalet Yüksekokulunun değerli öğrenclerini sevgiyle kucakliyorum.

72 nci yıldönümünü bundan 6 gün önce kutladığımız Cumhuriyetle hemen hemen yaşıt sayılabilecek olan Ankara Hukuk Fakültesinin 70 nci yıldönümünü kutluyoruz.

1920 'li ylllarda, bildiğiniz gibi Türkiye'nin üniversitesi yok. Bir Darülfüinunu var; Darülffünun 1932'de Büyük Atatürk'ün işaretiýle üniversiteye çevriliyor.

Hukuk Fakültesi, üniversiteden evvel kurulmustur, 1927'de; $1925^{\prime}$ te Hukuk Mektebi olarak başlamıştır. sayın Dekanımız izah ettiler ki, Hukuk Mektebi aslında bir yeni hukuk düzeni için yeni hukuk kuşağını yetiştirecek ve bir yeni hukuk çağı açacaktır. bu gerçek devrimdir. Çağdaş hukuk dediğimiz olay ile Türkiye geçmişle olan irtibatın kesmektedir. Cumhuriyet dediğimiz olay, sadece devletin şeklini değiştirmekten ibaret değil, toplumun yaşam tarzını değiştirmek ve yeni kaideler ortaya koymak, bu kaidelere göre de halkın yaşamını sağlamaktır.

İște, o günden bu yana 27 bin öğrenci bu büyük kurumdan mezun olmuş ve gerçeten yeni bir hukuk kuşağı teşkil etmişler, içlerinden birçok ilim adamlan çıkmış, ülkenin her köşesinde savcılar, hâkimler, avukatlar adaletin tevziine yardımcı olmuşlar ve Türkiye Cumhuriyeti Devletini bir hukuk devleti yapmak için gayret sarf etmişlerdir. 
Hukuk devleti, hukukun üstünlüğü gibi kelimeleri çok sık kullanıyoruz. Tabiî ki ben burada hukukun ne olduğnu sizlere anlatmaya çalışacak değilim. Ama, 45 senedir Türkiye Cumhuriyetinin hizmetinde bulunan birisi olarak ve bunun 30 senesinde de hak kavgası, hukuk kavgası -kendi anlayışıma göre- içerisinde olan birisi olarak, geçmişte Cumhuriyetin 72 yılında gördüğümüz çok önemli aşamalar vardır ve bu aşamaları Türkiye birikim kazanarak, tecrübe kazanarak, bedelini de ödeyerek aşarak geliyor.

Aslında hukukun üstünlüğü dediğimiz olay, çağdaş hukukun üstünlüğü dediğimiz olay iyi anlaşılmalıdır.

Çağdaş hukuk, yani uygar dünyanın benimsediği hukuktur ve bizim Cumhuriyet öncesindeki benimsediğimiz hukuktan farklıdır. Çünkü, çağdaş hukuk, aslında dinî esasların dikte ettiği hukuk değildir; çağdas hukuk, bürün uygar dünyanın laik düzen içerisinde benimsediği hukuktur.

Bunun ayırımında, -tabiî ki hukuk hocalarımız gayet dikkatle dururlar- bunun ayırımında önemli sonunlar vardır ve bugün de zaman zaman, eğer hâlâ birtakım tartışmalar yapılıyorsa, yapılabiliyorsa, bu bir etkinin, geçmişten gelen bir etkinin sebebiyledir. Ama, biz çağdaş hukuku benimsemişiz; çağdaş hukuku benimsediğimize göre çağdaş hukukun gerektirdiği çağdaş devlet şeklini benimsemişiz. Çünkiü çağdaş devlet şekliyle çağdaş hukuk fevkalade yakından ilgili.

$O$ gün o. Bugüne geldiğimiz yerde, bugün biraz daha durum değişiktir. Bugün söz konusu olan şey bizim kendi millî hukukumuzdur. Evet, bu çağdaş hukuktur, bu da tamam; fakat bugün olay evrensel hukuktur. binaenaleyh, evrensel hukukun getirdiği pek çok yeni kaideleri kabullenmek, benimsemek durumundayı, bu suretle biz aslında çağdaş ve evrensel hukuku benimsemiş bir ülke ve böylece uygar dünyayla aynı paralele girmiş bir ülke oluruz.

Binaenaleyh, nasıl yaşadığımız, ne yediğimiz, ne içtiğimizden önce geleni, "hangi kaidelere bağlıyız?", odur. Evrensel hukukun temelinde İnsan Hakları Beyannamesi, İnsan Hakjarı Avrupa Konvansiyonu ve Paris Şartı, Helsinki Şartı gibi, daha sonra Birleşmiş Milletlerin ortaya koyduğu, bizim de imzaladığımız Rio Deklerasyonu vesaire gibi dokimmanlar vardır. binaenaleyh, bunların hepsi bugün bizim hayat tarzımızı ve yönetim tarzımızı tayin eder. 
Öyleyse, hukuk dediğimiz zaman, aslında sadece okutanların ve okuyanlarn bilmesi lazım gelen bir olay değil, yaşayanların, yani bizâtihi hakkın sahibi olanlarn, hayatı yaşayanların, yani ülkenin vatandaşlarının onu bilmeleri lazımdır.

Yani demek istiyorum ki; hukuk dediğimiz olay sadece hukuk fakültesinde okunmakla, okutulmakla iktifa edilmeyecek kadar çok yaygin bir olaydır.

Eğer bir ülkenin insanları kendi haklarını bilmiyorlarsa, kendi haklarına sahip çıkma şuuruna sahip değillerse, o zaman hukuk dïzeni dediğimiz düzeni yaşatmakta zorluğunuz olacaktır. Hukuk düzenini yaşatamadığınız yerde, hukukun getirdiği esaslan uygulamak gayet tabii ki o kadar söz konusu olmayacaktır.

Demek istediğim şey şudur: İnsan Hakları Beyannamesi haklar getiriyor, oradan başlayalım.

Bu haklar, devredilemez haklardır. Bu haklar, parçalanamaz. haklardır, vazgeçilemez haklardır. Ben bir şart daha ekliyorum, müruru zamana uğramaz haklardır, yani zaman aşımına uğramaz. Peki, bu haklara sahip çıkacaksınız, bu hakları bileceksiniz, bunlara sahip çıkacaksınız. Ve peki, bu haklar kişiyi nasıl koruyacak? Işte orada devlet işin içine giriyor, devlet dediğimiz olay işin içine giriyor. Devlet dediğimiz olayla bu haklann çok yakından ilgisi var. Çünkü, devlet bir şemsiye olarak bu haklarn kişinin elinden almak için değil, aksine bu hakları temin etmek için giriyor.

\section{Devlet kim? Devlet kimin müessesesi?}

Tabiî ki devlet, Cumhuriyet öncesindeki rejimde devlet tepeden gelme bir devletti, hakkın sahibi oydu; hakkın sahibi halk değildi, devletin verdiği kadar halkın hakkı vardı. Hadise şimdi aksine dönmüsstïr. Ne olmuşıur? Vatandaşın hakları vardır, devlet bu haklara ahip çıkacak, onların korunmasına yardımcı olacakır. Yalnız, vatandaş kendi háklarına sahip değilse, devlet ister istemez bir yerden sonra otorite haline gelir, bu hakları korumaktan ziyade, bu hakları bir ipotek altına alır. $\mathrm{O}$ zaman haklar yetmiyor; hakkın sahibi olan toplum, -ki ona biz demokratik toplum diyoruz, çoğulcu toplum diyoruz- toplum kendi haklarına sahip olacak, onu bilecek, onlara sahip olacak ve o hakları kullancaktır. Ve bu hakların içerisinde devletle toplumu bağlayan en önemli hak, halkın idareye iștirak hakkıdır. İşte burada sanıyorum ki çok önemli bir çizgi çizile- 
cektir. Bu, meşruiyet kaidesidir. Yani, eğer bir ülkede kullanılan yetkilerin, devletin bütün ünitelerinin kullandığı yetkilerin, tümüyle ama devletin, yargı organı dahil, kullandığı yetkilerin menşei halkta değil ise orada meşruiyet aranamaz. Veya şöyle diyelim; bir ülkede kullanılan hakların tümünün menşei halk olacaktır. Bunun olabilmesi için hâkimiyetin kayıtsız şartsız millete ait olması lazımdır ki, Büyük Atatürk'ün Cumhuriyetin temeline koyduğu en önemli harç, hâkimiyetin kayıtsız şartsız millete ait olmasıdır.

Ben 35 seneye yakın hâkimiyetin kayıtsız şartsız millete ait olmasının kavgasını yaptım. Ve şunu ifade edeyim ki; eğer millet kendi hâkimiyet hakkını kullanabiliyorsa, -bir devletin bağımsız olması yetmez, halkının hükümran olması lazımdır- eğer bir ülkenin halkı hür iradesiyle kendisini yönetecekleri iş başına getirebiliyorsa ve götürtebiliyorsa; kansız, kavgasız, entrikasız bu iş cereyan edebiliyorsa her işinizi çözersiniz.

Ve şunu hemen burada ifade edeyim ki, halk kendisini yönetecekleri seçsin diyoruz. Ee, halk cahil. Halk cahilse kendisini yönetecekleri nasıl seçecek, yani nasıl isabetli davranacak? Öyleyse, halkın seçtikleri değil, elit, yani aydın ülkeyi idare etmelidir. $O$ zaman halkı cahil olduğ için bir kenara bırakıp, halkı idare eden değil, idare edilen olmaya mahkûm etmekten başka çareniz yoktur. Bu kaide yanlıştır. "Hâkimiyet kayıtsız şartsız milletindir" dedikten sonra, "ama"sı ve "fakat"1 yoktur. Neden yoktur? Çünkü, eğer halk hürse, -orta yerde bir postiilat, bir aksiyon, bir mütearife vardır, halk hürse doğru yapar. Çoğunluk aldanmaz, çoğunluk kaidesi, çoğunluk aldanmaz. Ve "Néreden bilelim çoğunluğun aldanmayacağ1nı?" demeyeceksiniz; işte bunun adına da demokrasi inancı diyorlar. Demokrasiye inanmıyorsak, o zaman aslında hakların tümünün şemsiyesi olan devlet demokratik devlet değilse, devletin keyfî olmaktan kurtulması mümkün değildir. Onun içindir ki, keyfî devletin yerine halkın devletini ikame ediyorsak, bunun köküne mutlaka halkın hür iradesiyle seçme ve seçilme hakkını koyacaksınız.

1995 Türkiyesinde, Türkiye Cumhuriyetinin temelinde Büyük Atatürk'ün koyduğu millî hâkimiyet kaidesi işlemektedir.

Ve "adalet mülkün temelidir." Cumhuriyetin millî hâkimiyet prensibi kadar önemli bir diğer kaidesi budur, adalet muilkün temelidir. 
Bu aslında her devlet için doğrudur, her rejim için de doğrudur. Yalnız, adaletin mülkün temeli olabilmesi için, bu ülkenin yasalannın anayasaya uygun olması, anayasanın da kissinin vicdanına uygun olması lazımdır. Ve kişinin vicdanına uygunluğu, $o$ anayasaların hakın referandumundan geçmiş olmasıyla tescil edilir.

"Referandumdan geçmişse kişinin vicdanina uyar mı, uymaz mı?" tartışmaları yapılabilir; ama asgarîden bu şartın yerine gelmiş olması lazımdır. Ve bu suretle yasaları eğer halkın seçtiği yasama meclisleri, halkın hür iradesiyle seçtiği yasama meclisleri seçiyor ve o anayasal kontroldan geçiyorsa, o zaman o yasalar halkın vicdanına uyan yasalar olarak telakki edilecektir. Ne zamana kadar? Yanlışlığı halkın çoğunluğu tarafından kabul edilip değiştirilinceye kadar ve ona uyulacaktır.

Ve demokrasinin, hukuk devletinin, hukuk üstünlügüünün halkın vicdanında, gözünde ve gönlünde yaşaması lazımdır. Bunun yaşayabilmesi için sistemin işlemesi lazimdır. sistemin; yasama organının işlemesi lazımdır, yürüitme organının işlemesi lazımdir, yargı organının işlemesi lazımdır, bütün kurumlannın işlenmesi lazımdır ve bunun da ahenk içinde işlemesi lazımdır. Eğer bu olabiliyorsa, oturmuş bir demokrasiye sahipsiniz; eğer bu olabiliyorsa, temel hak ve hürriyetler korunuyor, bu olabiliyorsa çağdaş bir hukuk devletine sahipsiniz; bütün gayretler bunun içindir.

Ve dünyadaki 184 tane devletin içinde 75 tanesini demokratik sayıyorlar; bunların içerisindekinin bir kısmının demokrasilerinin oturmuş olduğunu kabul ediyorlar, bir kısmının oturmamış olduğunu kabul ediyorlar, bir kısmının "frajil" olduğunu kabul ediyorlar, bir kısmın da demokrasiden ziyade bir nevi şibih demokrasi... Şibih; bilmiyorum şimdiki hocalarımız öğrencilere "şibih" lafını ögretiyorlar mi?.. İşte pembemsi, mavimsi gibi, yani demokrasi değil, bir yarı demokrasi de demiyoruz, ona benzer bir şey. Demokrasinin sana göresi, bana göresi, ona göresi yoktur, yarımı, yamalağı, şibihi yoktur; demokrasi standart kaidelere oturacaktır. "Biz yaptik oldu" da olmaz, "Bizim domekrasimiz böyle" de olmaz. Öyleyse, standart bir demokrasiyi meydana getireceksiniz.

Türkiye'de demokrasi 50 seneye yakın süredir, çok partili demokrasiye geçtiğimizden bu yana çok örselenmiştir. Örselenmiştir ama, yine demokrasinin bütün kurumları bugün mevcuttur ve başımız suyun üstündedir. 
Eksiklerimiz, noksanlanmız vardır. Bu eksikleri noksanları tartışarak tamamlayacağız. Ve bu ülkenin insanları düşüncelerini söyleyerek (bu düşünceler zaman zaman rahatsız edici bile olabilir, ama bu düşünceler mutlaka söylenmelidir) bunların bir özünü, hülasasını, doğnuyu bunların içerisinden çıkararak yol alacağız.

Büyük Atatürk'ün kurduğu bu büyük okulun kökünde yatan şey, gerçek bir tanedir ve gerçeği bulmak da müşkülat çekmeyiniz. Gerçeği bulmakta müşkülat çekmemek için hadiseyi iyi bilmeye, doğru muhakeme etmeye ve doğru yargıya varmaya mecburuz.

Ve bugün için Türkiye'nin övünülecek birtakım şeyleri var, sıkıntılarının yanında övünülecek şeyleri var. Sahip olduğu övünülecek şeylerden bir tanesi, Türkiye'nin bir hür yargı organına sahip olmasidır.

Sizin yetiştirdiğiniz, bu müessesenin yetiştirdiği pek çok ve diğer fakültelerimizin, okullarımızın yetiştirdiği pek çok hukuk okumuş hâkimimiz, savcımız, avukatımız, Türkiye'de yargı müessesesini gerçekten övünülecek bir seviyeye getirmişlerdir.

Gayet açıklıkla söylïyorum ki, herkese de söylïyorum, Türkiye'de yargı bağımsızdır. Binaenaleyh, sav, savunma ve karar zinciri işlemektedir. Hiç kimse çıkıp "Bunun üzerinde siyasî nüfuz vardır" diyemez.

Meydan okuyorum, "Bunun üzerinde siyasî nüfuz vardır" diyen varsa, bunun kavgasını ben yapacağım. binaenaleyh, ben böylece devletimin "adalet mülkün temelidir" şeklindeki temel kaidesine hizmet edenlerin hepsine serbestçe, rahatça çalışabilmelerinin şemsiyesini tutuyorum.

Onlardan istediğmiz şey, hür vicdanlariyla karar vermektir.

Binaenaleyh, hür vicdan çalışıyorsa, hiç endişe edilmesin yine ülke her meselesini çözer ve eğer bir ülkede adaletsizlik yaygın haldeyse o ülkenin içinden çıkmak mümkün değildir. Orada ne devlete inanç olur, ne demokrasiye inanç olur, hiçbir şeye inanç olmaz.

Binaenaleyh, demokrasi de devlet te adaletle başlar. Ondan sonrası ondan sonradir. 
Ve bugün yargı organımızın daha iyi, daha hızlı, daha çabuk işlemisini isteyen çok kimse vardır Türkiye'de. Bu ayn bir meseledir.

Yargı organımızın daha çabuk, daha iyi, daha hızlı işlememesi yargı organının kusuru değildir. Birçok kere mevzuat gözden geçirilmiştir; yargı organı fevkalade yüklüdür ve bu yüklerin bir kısmının yargı organı üzerinden alınması lazımdır. Yargı mahiyetinde olmayacak, pekâlâ mahkemeye gelmeden halledilebilecek birtakım Hazinenin meseleleri idi, yok ormanın meseleleri idi vesaire gibi birtakım şeyleri yargı organımızın uistünden almak lazım. Ve yargı organının çalışmasını hızlandıracak şekilde, yargının niteliğini bozmamak şartıyla; çünkü, dağıtılmayan adalet en büyük adaletsizliktir; bu takdirde adaletin daha süratle dağıtılması, ama niteliğini de mutlaka koruması lazımdır.

Şimdi, bu Fakülteden mezun olan genç hukukçulara sesleniyorum, diyorum ki; 60 milyon Türkiye'de kalkınan, çırpınan, gelişen ve fevkalade dinamik bir halkın hizmetine gidiyorsunuz. Hâkim olarak gidiyorsunuz, savcı olarak gidiyorsunuz, avukat olarak gidiyorsunuz veya serbest meslek erbabı olarak gidiyorsunuz veya ileride siyasetçi olarak gidiyorsunuz; ama, burada ögrendiklerinizin çok faydasını göreceksiniz. Çünkü, Ankara Hukuk Fakültesi, yani bizim hukuk fakuiltelerimiz çok güzel bir eğitim veriyor. Kendileriyle çalışmaktan fevkalade gurur duyduğum pekçok arkadaşım bu fakültteden mezundur. Ve gerek Türkiye'nin geçmişine, gerek Türkiye'nin bugününe ve geleceğine bakarken çok güzel şeyleri ortaya koymuşlardır. Bugünkü yasalarnn hemen hemen çoğunda onların hissesi vardır. Yasama organinin içerisinde olarak, yargı organının içerisinde olarak veya avukatlık kısmında olarak da hukukun işlemesine yardımct olmuşlardır.

Hepinize başarılar diliyorum. Hepinize başarılar diliyorum ve adaletin tevziine, Türk vatandaşının Türk adaletine olan güvenine hizmet edeceksiniz ve bunda mutlaka başarılı olacağınızdan eminim.

Değerli hocalanmız sizinle övünecektir, biz de sizinle övüneceğiz. Hepinizi kucaklıyorum, hepinizin gözlerinden öpüyorum, başarilar diliyorum, sevgiler sunuyorum. 